\title{
Demens til folket!
}

\author{
I årets TV-aksjon måtte jeg legge \\ fordommene mine igjen ved døra. \\ Det håper jeg flere vil gjøre.
}

Jeg vet ikke helt hva jeg forventet. Sykehjemssenger kanskje. Voksne som var som barn. Dager som ikke kunne bli bedre. Mennesker som allerede var borte. Men der, i Nasjonalforeningen for folkehelsens lokaler, opp trappa, inn gjennom døra, satt seks smilende menn i sin beste alder. Midt i livet med hver sin diagnose. Jeg fikk kaffe i koppen, kjeks i hånda og stol å sitte på. Så ble det stille.

- Jeg lurer på, kremtet jeg, med mine egne forestillinger fortsatt luskende ved $d ø r$ stokken. - Hva er de vanligste fordommene mot folk som har en demensdiagnose?

- At vi er dumme!

- At det er flaut.

- At det ikke finnes noen måte for oss å ha et godt liv.

Jeg måtte se ned i kaffen min.

I Norge har rundt 70000 mennesker diagnosen demens. Noen er virkelig blant våre aller eldste, pleietrengende og sengeliggende. Noen er aktive eldre som ønsker seg ut, ønsker å løpe eller synge, gå på ski eller lese bøker. Noen er som denne gjengen ressurssterke, middelaldrende med unge barn, lange CV-er og en pensjonisttilværelse som kom plutselig og uønsket.

Noen få er på min alder. De er i 30- og 40-årene. De har barn og foreldre. De har belånt hus og studiegjeld. Demenssykdommen har så mange flere ansikter enn jeg trodde da jeg begynte å jobbe med årets TV-aksjon. Den har ansiktet til gutta i denne samtalegruppa hos Nasjonalforeningen.

- Det er ikke så lenge siden jeg var leder for en stor bedrift, men akkurat nå husker jeg ikke helt hva den bedriften het.

- Inntil for noen måneder siden kunne jeg fremdeles handle i aksjer. Men nå merker jeg at jeg er i ferd med å forandre meg. Jeg kan ikke lenger ta den sjansen.

- Det er vondt for en som alltid har klart seg seg, en voksen mann, plustelig å stå på gata og ikke vite noen ting. Å måtte sette seg på nærmeste benk og vente. Vente på å komme til seg selv eller på å bli funnet.

Den har ansiktet til en gutt på åtte som som sitter ved et spisebord og skyver til side tallerkenen med stekte poteter og kyllingform. - Vil du se bilde av faren min? spør han. - Her er han!

Og der er han. Ikke 40 ennå, en tullegrimase inn i sønnens kamera.

Og en time senere på sykehjemmet. Et helt annet blikk. Det er fremdeles noen der inne. Noen med en fjern assosiasjon eller en følelse jeg ikke får tak i. Men ingen ord som gir mening. Ingen minner som knytter dagen i dag til det bildet jeg nettopp har sett. Og milde sykepleierhender som lukker og låser meg ut av skjermet avdeling.

Den har ansiktene til paret som hadde planlagt pensjonisttilværelsen. Til hun plustelig sto der med alle ingrediensene til middagen, men ikke visste hvordan den skulle settes sammen. Til hun en dag satt ved frokostbordet og savnet mannen sin. Han som måtte ha forlatt henne. For han var ikke den gamle mannen som satt rett overfor henne ved bordet. Han som hver morgen henger fram et utvalg av gensere, bukser og jakker så hun skal få velge uten å bli overveldet.

Den har ansiktet til avdelingssykepleieren i Oslo øst som finner fram til barnesanger på urdu og punjabi for dem som ikke har sine minner i Vera Lynn og Blåveispiken. Og til henne som smiler i den samiske sansehagen og fremdeles kan joike og steke blodpannekaker, men har glemt alle norske ord.

Det var ikke før på sending at jeg virkelig skjønte betydningen av å vise fram alle disse ansiktene. Aldri har telefonene ringt så ofte og lenge. Det var mennesker som hadde holdt diagnosen hemmelig, men endelig torde fortelle. Det var pårørende som hadde slitt helt alene, men endelig følte seg som del av noe større enn seg selv. Det var de som mistenkte at noe var galt og endelig bestemte seg for å ringe demenslinjen og få svar på spørsmålene som hadde plaget dem så lenge.

Men selv om alle som fortalte sin historie i årets TV-aksjon har skapt større åpenhet, er mye ved det gamle.

- Hva skjer når jeg eller en jeg er glad i får diagnosen demens? spurte jeg leder for Nasjonalforeningen for folkehelsens demensråd, Wenche Frogn Sellæg.

- I mange kommuner, ofte ingenting, svarte hun.

Jeg så for meg alle dem jeg har truffet gjennom arbeidet med demenssaken.

Hvordan fremtiden plutselig var blitt totalt forandret. Og jeg så for meg hvordan det må være å stå i det helt alene. Eller med et støtteapparat som ikke kan sykdommen og ikke er tilpasset den.

De 224 millionene kommer godt med. Det skal forskes og informeres og opprettes tilbud til både demenssyke og pårørende. Men like mye håper jeg at ny åpenhet fører til høyere status og ny kunnskap. At både bussjåføren, naboen og kassadamen, forskeren og fastlegen på hver sin måte kan sørge for at ingen skal måtte stå alene i kampen mot de nådeløse demenssykdommene. $\mathrm{Og}$ at det er rom for at den som får en demensdiagnose, ikke er en sykdom, men et helt menneske.

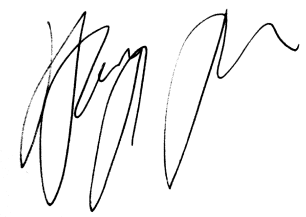

Tidsskr Nor Legeforen nr. 1, 2014; 134 